IZA DP No. 5539

Whose Children Gain from Starting School Later?

Evidence from Hungary

Szilvia Hámori

János Köllő

February 2011 


\title{
Whose Children Gain from Starting School Later? Evidence from Hungary
}

\author{
Szilvia Hámori \\ IE, Hungarian Academy of Sciences \\ János Köllő \\ IE, Hungarian Academy of Sciences \\ and IZA
}

Discussion Paper No. 5539

February 2011

IZA

P.O. Box 7240

53072 Bonn

Germany

Phone: +49-228-3894-0

Fax: +49-228-3894-180

E-mail: iza@iza.org

Any opinions expressed here are those of the author(s) and not those of IZA. Research published in this series may include views on policy, but the institute itself takes no institutional policy positions.

The Institute for the Study of Labor (IZA) in Bonn is a local and virtual international research center and a place of communication between science, politics and business. IZA is an independent nonprofit organization supported by Deutsche Post Foundation. The center is associated with the University of Bonn and offers a stimulating research environment through its international network, workshops and conferences, data service, project support, research visits and doctoral program. IZA engages in (i) original and internationally competitive research in all fields of labor economics, (ii) development of policy concepts, and (iii) dissemination of research results and concepts to the interested public.

IZA Discussion Papers often represent preliminary work and are circulated to encourage discussion. Citation of such a paper should account for its provisional character. A revised version may be available directly from the author. 
IZA Discussion Paper No. 5539

February 2011

\section{ABSTRACT}

\section{Whose Children Gain from Starting School Later? Evidence from Hungary ${ }^{*}$}

We look at the effect of school starting age on standardized test scores using data covering all grade four and grade eight students in Hungary. Instrumental variables estimates of the local average treatment effect suggest that children generally gain from starting school one year later and the effects are much stronger in the case of students coming from loweducated families. We test the robustness of the results by allowing for heterogeneity in the age effect, distinguishing between fields of testing, using discontinuity samples and relying on alternative data. The hypothesis that delayed entry has a stronger impact on low-status children is supported by the robustness checks. The observed patterns are most probably explained by the better performance of kindergartens, as opposed to schools, in developing the skills of low-status children.

JEL Classification: $\quad 121,128, \mathrm{~J} 24$

Keywords: education, student test scores, enrolment age, identification

Corresponding author:

János Köllő

Institute of Economics of the Hungarian Academy of Sciences

Budaörsi út 45

1112 Budapest

Hungary

E-mail: kollo@econ.core.hu

\footnotetext{
* The authors are grateful to Gábor Kertesi, Zoltán Hermann and Dániel Horn (Institute of Economics, Budapest) for instructions on how to use the NABC data and for helpful comments. We also thank Bernd Fitzenberger, Zsuzsanna Gulybán, Anna Lovász, Andrea Mühlenweg, Friedhelm Pfeiffer, Júlia Varga and Stefan Wolter for comments on earlier versions as well as seminar participants at the Johann Wolfgang Goethe-University in Frankfurt and conference participants of the Hungarian Academy of Sciences in Szirák. This paper was prepared in part while Szilvia Hámori visited the Swiss Leading House "Economics of Education", whose hospitality is gratefully acknowledged.
} 


\section{Introduction}

We look at the effect of school starting age on standardized test scores using data from Hungary's National Assessment of Basic Competencies (NABC), which covers all grade four and grade eight students in the country. Students are typically aged $10-11$ and $14-15$ at the time of testing because of the variation in their school starting age. ${ }^{1}$

We estimate the local average treatment effect (LATE) of delayed start using an instrumental variable (IV) model, which exploits the exogenous variation in school starting age driven by the cut-off date for enrolment and children's month of birth. We test the robustness of the results in four ways: by allowing for heterogeneity in the age effect, distinguishing between tests of literacy and numeracy, using discontinuity samples and relying on alternative data.

The impact of social background on academic test scores is nowhere as strong among the countries participating in PISA 2006 as in Hungary (Jenkins et al. 2008). In view of this fact, we are particularly interested in the question of how delayed start affects low-status students. Therefore, we estimate the models for the children of low- and high-educated mothers separately, taking advantage of the exceptional size of the NABC samples. Late entry is expected to have an equality-enhancing effect if pre-school institutions and/or families perform better in developing the skills of low-status children (relative to their high-status counterparts) than primary schools. In the Hungarian context, we expect that repeating the school preparation year in the less segregated environment of the compulsory kindergarten - rather than going to a low-quality school from age six - can help many disadvantaged and/or discriminated children catch up with their high-status classmates.

The LATE estimates strongly support our key hypothesis. Unlike the OLS results, which misleadingly indicate that late entrants perform below average, the IV estimates yield evidence that children generally gain from starting school one year later. The effects are significantly stronger in the case of students coming from low-educated families. For them, the LATE estimate exceeds 80 and 35 percent of the standard deviation of the composite cognitive-academic test score in fourth and eighth grades, respectively. The children of mothers with a tertiary degree benefit far less from a late start: the effects fall short of 30 percent and 20 percent in grades four and eight, respectively.

We find the between-group differences to be larger at age $10-11$ than at age $14-15$ : the equityenhancing effect of delayed start seems to fade away as children progress through school. However, given the practice of early tracking in the Hungarian school system, achievement at age $10-11$ is of great importance.

When checking the robustness of the results, we first allow for heterogeneity in the age effect. The LATE identifies the age effect for children whose entrance age is influenced by the cut-off date and is only informative of the entire student population in case of model homogeneity, that is, if the age

\footnotetext{
${ }^{1}$ School starting age is strongly affected by the cut-off date for primary school enrolment and parental decisions. Children born after 31 May are expected not to start primary school in the year they reach age six. Furthermore, within certain limits, parents are allowed to request both early and delayed primary school enrolment.
} 
effect for those affected by the instrument does not differ from the age effect for those who are selected into delayed enrolment voluntarily. Therefore, we further analyse the data following the control function approach proposed in Garen (1984) to produce consistent estimates of the average treatment effect (ATE), which measures the impact of delayed start for a randomly selected child. (To the best of our knowledge, we are the first to apply this model to the subject under examination.) The ATE estimates substantially lag behind the LATEs, suggesting that children born before the cutoff date and selected into delayed enrolment by their parents, kindergarten teachers and/or the body of educational counsellors benefit less from the postponement, on average, than do those, whose birthday falls after the cut-off date. Even so, most of the ATE estimates are significant for disadvantaged children. In their case, the estimates amount to about 40 percent of the standard deviation of the composite cognitive-academic test score in the fourth grade and 20 percent in the eighth grade. The ATE estimates for the high-status children are typically insignificant and fall short of 10 percent.

Second, we estimate LATE for reading and mathematics tests separately. The finding that the effect of delayed start is stronger for low-status children continues to hold.

Third, the LATE estimates remain significant and follow the same pattern in the discontinuity samples comprising children born in a four-month range around the cut-off date.

Finally, we repeat the analysis using the Hungarian sub-samples of PIRLS and TIMSS. ${ }^{2}$ The LATE estimates follow the same pattern as those identified in the NABC (the effects are stronger for disadvantaged children) but most of the coefficients estimated for the small samples (no more than 3 -5 percent of the NABC population) are statistically insignificant.

The paper is structured as follows: Section 2 discusses the methodological difficulties of estimating the impact of school starting age on academic achievement, gives an overview of the solutions proposed in the literature and introduces the IV and control function approaches. Section 3 introduces the Hungarian primary school enrolment cut-off date regulation and argues why the issue of delayed entry is important in a highly segregated school system. Section 4 describes the data sources. The LATE estimates and the results or the robustness checks are presented in Sections 5 and 6 , respectively. Section 7 concludes.

\section{Methodological considerations}

\section{A The effects of school starting age and the difficulties of identification}

The effect of school starting age operates through a number of different pathways as discussed in Black et al. (2008), Cascio and Schanzenbach (2007), Datar (2006), Fredrikkson and Öckert (2006), Leuven at al. (2010) and McEwan and Shapiro (2007). (i) Children who delay enrolment are older at the time of testing and subsequently have more accumulated knowledge, implying an age-at-test effect. (ii) Delayed enrolment also increases children's absolute age of enrolment, whereby older children have the necessary cognitive, social, linguistic or physical maturity to perform better in each grade, implying an absolute age effect (iii) Delayed enrolment also increases a child's age relative to

\footnotetext{
${ }^{2}$ PIRLS: Progress in International Reading Literacy Study. TIMSS: Trends in Mathematics and Science Study.
} 
his/her classmates, entailing a relative age effect. Relatively older students may benefit from delayed entry if the curriculum is geared towards the average student's level of development (Datar 2006). Furthermore, relatively older students may outperform younger ones by virtue of their relative maturity which permanently boosts their achievement - for example through self-confidence and attention that come from being the oldest in the class (Cascio and Schanzenbach 2007).

The major challenge in estimating the effect of school starting age on achievement is that students with delayed entry are not randomly selected if parents have some choice regarding the timing of primary school enrolment, as is the case in Hungary. In order to overcome the problem of selfselection, numerous empirical studies (including Bedard and Dhuey 2006, Black et al. 2008, Cascio and Schanzenbach 2007, Datar 2006, Elder and Lubotsky 2009, Fertig and Kluve 2005, Fredrikkson and Öckert 2005, Hámori 2008, Leuven et al. 2004, McEwan and Shapiro 2008, Puhani and Weber 2007 and Strøm 2004) exploit the exogenous variation in school starting age driven by the cut-off date regulation and the children's month of birth to estimate IV models. Our benchmark model will follow this identification strategy by using expected school starting age as an instrument for actual school starting age.

The IV estimates capture the LATE: the average causal effect of the treatment for those who comply with the assignment mechanism of the instrument i.e. compliers (Imbens and Angrist 1994). ${ }^{3}$ In our case, the LATE identifies the effect of school starting age for those children, who start school later because their birthday falls after the cut-off date. The existence of heterogeneous treatment effects in the model implies that the LATE may not be informative for the entire student population (Angrist 2004, Angrist and Pischke 2009). In order to incorporate treatment effect heterogeneity, a control function approach is proposed by Garen (1984), an extension of the IV-model. The control function estimates the average treatment effect (ATE), that is, the gain to starting school later for a randomly chosen child.

In the absence of longitudinal data, we follow Bedard and Dhuey (2006), Elder and Lubotsky (2008) and McEwan and Shapiro (2007) in that we try to identify the persistence of the age effect and the underlying mechanism by comparing the estimates at two points in the school career. If the age-attest effect dominates, the estimated impact fades over time since the knowledge accumulated in the early years will represent a smaller fraction of the stock of knowledge as children progress through school. By contrast, the absolute and relative age effects imply that late school entrants learn at a higher rate in each grade and perform better relative to their younger counterparts at both points in time.

\footnotetext{
${ }^{3}$ The local average treatment effect (LATE) framework (introduced by Imbens and Angrist 1994) partitions any population with an instrument into three instrument-dependent subgroups: compliers, always-takers and never-takers. The treated group, those children who start school at the age of seven, is composed of compliers (those children who start school at the age of seven because their birthday falls after the cut-off date) and always-takers (those children who start school at the age of seven voluntarily, irrespective of their birthday). The non-treated group is composed of compliers (those children who start school at the age of six because their birthday falls before the cut-off date) and never-takers (those children who start at the age six voluntarily, irrespective of their birthday). The LATE is not informative about the effect on school starting age on nevertakers and always-takers because for these two groups the treatment status is unchanged by the instrument. (Angrist and Pischke 2009)
} 
With the data at hand, we cannot examine the lifetime effects of school starting age. ${ }^{4}$ However, given the features of early tracking and dead-ends in the Hungarian education system, performance at grades four and eight is important in itself, as it strongly influences the type and quality of secondary education, which in turn has a strong impact on the possibility of going on to further education and finding decent jobs. ${ }^{5}$

\section{B Estimation strategies}

The simplest way to capture the effect of school starting age $A_{i}^{s}$ on test score $Y_{i}$ holding student, family and school background variables $X_{i}$ constant is by estimating an ordinary least squares (OLS) regression similar to (1):

$$
Y_{i}=\beta_{1}+\beta_{2} A_{i}^{s}+X_{i}^{\prime} \beta_{3}+\varepsilon_{i}, \quad i=1, \ldots, n
$$

In countries where there is teacher and parental choice concerning the date of school enrolment, actual school starting age $A_{i}^{s}$ and the disturbance term $\varepsilon_{i}$ may be correlated. It may be the case that (i) ambitious parents prefer early enrolment, (ii) wealthier parents are less sensitive to the additional costs of a longer compulsory education and hence may prefer a later start (iii) children with lower (higher) abilities start school a year later (earlier) than proposed by the cut-off date regulation. If the non-random pattern of enrolment is such that, on average, less able children enter school a year later, the OLS estimate $\beta_{2}$ for the effect of school starting age on test score will be downward biased.

Subsequently, recent empirical studies rely on IV estimation to identify the age effect, exploiting the exogenous variation in school starting age driven by the children's month of birth and the cut-off date regulation for enrolment. Accordingly, expected school starting age $A_{i}^{E}$, defined as the age when the child is supposed to start school according to the regulation is used as the instrument for actual school starting age $A_{i}^{S}$. The validity of the IV approach depends on two conditions: (i) $\operatorname{Cov}\left(A_{i}^{S}, A_{i}^{E}\right) \neq 0$ (instrument relevance) and (ii) $\operatorname{Cov}\left(\varepsilon_{i}, A_{i}^{E}\right)=0$ (instrument exogeneity).

Formally, in the IV approach, the first-stage regression involves a regression of $A_{i}^{S}$ for individual $i$ on the instrument $A_{i}^{E}$ and the vector of control variables to obtain the fitted values $\hat{A}_{i}^{S}$ :

$$
A_{i}^{S}=\alpha_{1}+\alpha_{2} A_{i}^{E}+X_{i}^{\prime} \alpha_{3}+\varepsilon_{S i}, \quad i=1, \ldots, n
$$

where $\varepsilon_{S i}$ is a random disturbance term which contains the unobserved determinants of children's actual school entry age such as physical, intellectual, mental and social maturity.

\footnotetext{
${ }^{4}$ There is mixed evidence on the long-run effects of school starting age such as highest educational attainment, wages and the probability of employment. See for example Angrist and Krueger (1992), Black at al. (2008), Dobkin and Ferreira (2010) and Fredriksson and Öckert (2005). See also Bertschy et al. (2009) for the effect of cognitive competencies measured while in compulsory education on transition to the labour market.

${ }^{5}$ See Appendix Figure A1 for an overview of the Hungarian school system.
} 
The second stage involves a regression of test score $Y_{i}$ for individual $i$ on $\hat{A}_{i}^{s}$ and $X_{i}$ :

$$
Y_{i}=\beta_{1}+\beta_{2} \hat{A}_{i}^{S}+X_{i}^{\prime} \beta_{3}+\varepsilon_{i}, \quad i=1, \ldots, n
$$

where $\varepsilon_{i}$ is a random disturbance term which contains the unobserved determinants of student performance such as ability.

As discussed above, the IV model identifies the LATE: the average causal effect of the treatment for those who comply with the assignment mechanism of the instrument (Imbens and Angrist 1994). The LATE may not be representative for the entire population i.e. inference for populations other than that affected by the instrument requires homogeneity assumptions (Angrist and Pischke 2009).

The control function approach (Garen 1984) produces consistent estimates of the causal effect for a randomly selected individual i.e. average treatment effect (ATE). The control function approach, in addition to the bias due to correlation between the unobserved determinants of test performance and actual school starting age, accounts for unobserved heterogeneity in the age effect and is therefore an extension of the IV approach. In essence, the control function approach makes assumptions about the covariances of the two unobserved components and the observed covariates, and includes additional terms in the test equation to capture these relationships. See Card (1999, 2001) for the application of the control function approach in the context of schooling models.

In order to incorporate heterogeneity in the age effect, the test equation can be rewritten as follows:

$$
\begin{array}{lr}
Y_{i}=\beta_{1}+\beta_{2 i} A_{i}^{s}+X_{i}^{\prime} \beta_{3}+\varepsilon_{i}, & i=1, \ldots, n \\
Y_{i}=\beta_{1}+\bar{\beta}_{2} A_{i}^{s}+X_{i}^{\prime} \beta_{3}+\varepsilon_{i}+\left(\beta_{2 i}-\bar{\beta}_{2}\right) A_{i}^{s}, & i=1, \ldots, n
\end{array}
$$

where $\bar{\beta}_{2}$ is the average age effect and $\varepsilon_{i}+\left(\beta_{2 i}-\overline{\beta_{2}}\right) A_{i}^{S}$ is a composite disturbance term, which represents the two sources of unobserved heterogeneity: the first component of the disturbance term $\varepsilon_{i}$ represents individual characteristics which affect the test score and $\left(\beta_{2 i}-\bar{\beta}_{2}\right)$ represents the heterogeneity in the age effect i.e. $\beta_{2 i}$ is the individual deviation from the average effect $\bar{\beta}_{2}$. For simplicity of notation we denote the term $\left(\beta_{2 i}-\bar{\beta}_{2}\right) \equiv \eta_{i}$.

In addition to the IV assumptions of instrument relevance and instrument exogeneity, the model assumes that the two unobserved heterogeneity components are mean independent (uncorrelated) of the instrument $A_{i}^{E}$ :

$E\left[\varepsilon_{i} \mid A_{i}^{E}\right]=0$ $i=1, \ldots, n(6)$

and

$$
E\left[\eta_{i} \mid A_{i}^{E}\right]=0
$$$$
i=1, \ldots, n(7)
$$ 
A further assumption is that the conditional expectations of the two unobserved heterogeneity components $\varepsilon_{i}$ and $\eta_{\mathrm{i}}$ are linear in $A_{i}^{S}$ and $A_{i}^{E}$. This assumption in combination with that in equations (6) and (7) yields:

$E\left[\varepsilon_{i} \mid A_{i}^{S}, A_{i}^{E}, X_{i}\right]=\beta_{4} \varepsilon_{S i}$ $i=1, \ldots, n$

and

$E\left[\eta_{i} \mid A_{i}^{S}, A_{i}^{E}, X_{i}\right]=\beta_{5} \varepsilon_{S i}$ $i=1, \ldots, n(9)$

where $\varepsilon_{s i}$ is defined in equation (2). Adding the two control functions to the test equation yields:

$Y_{i}=\beta_{1}+\bar{\beta}_{2} A_{i}^{s}+X_{i}^{\prime} \beta_{3}+\beta_{4} \hat{\varepsilon}_{S i}+\beta_{5} A_{i}^{s} \hat{\varepsilon}_{S i}+\tilde{\varepsilon}_{i}$ $i=1, \ldots, n(10)$

Accordingly, the implementation of the control function regression consists of a two-stage procedure where consistent estimate of the error term $\hat{\varepsilon}_{S i}$ is first obtained from the OLS estimation of Equation (2) and in the second stage, equation (10) is estimated with OLS. The control function approach yields consistent estimates for the average effect of age on test score $\bar{\beta}_{2}$, which is equivalent to the ATE. Note that estimating the test equation with the additional regressor $\hat{\varepsilon}_{S i}$ but without the interaction of $A_{i}^{S}$ and $\hat{\varepsilon}_{S i}$ is numerically equivalent to the standard IV estimation.

\section{THE LOCAL CONTEXT}

\section{A School starting age regulation in Hungary}

According to the compulsory education law, children who turn six by 31 May are required to start primary school in September, while children born after the cut-off date are required to wait an additional year in order to enrol. The expected school starting age $A_{i}^{E}$ is thus generated using the cut-off regulation $c$ and birth month $b_{i}$ for individual $i$ and can be written as follows:

$A_{i}^{E}=\left\{\begin{array}{l}\frac{72+9-b_{i}}{12} \text { if } 1 \leq b_{i} \leq c \\ \frac{84+9-b_{i}}{12} \text { if } c<b_{i} \leq 12\end{array}\right.$

Given that the cut-off date is May, $c=5, A_{i}^{E}$ is between 6.33 years for the youngest children born in May and 7.25 years for the oldest children born in June. Children born in January start school at the age of 6.68 years, and there is a month-for-month decrease in $A_{i}^{E}$ until May. Between May and June, $A_{i}^{E}$ jumps up by 11 months, and falls again between June and December. 
The compulsory education law allows for flexibility concerning the school starting age within certain limits. First, children may start school at the age of six if they turn six years old before 31 December. Second, children born between 1 September and 31 May may delay primary school enrolment by one year. Both early and delayed enrolment may be requested by the parents, and the final decision is made by schools based on the kindergarten teachers' recommendation and/or the opinion of a body of educational counsellors. ${ }^{6}$ At this point, it is important to mention that both kindergarten and school education is free of charge, subsequently, there is no additional childcare cost imposed on parents whose children stay in kindergarten instead of starting primary school.

Table A1 in the Appendix presents the school enrolment patterns for the three datasets used in the analysis. As opposed to voluntary early enrolment, voluntary delayed enrolment is common in Hungary: 19 percent of the fourth graders in the NABC sample were enrolled in school a year later voluntarily. Voluntary delayed enrolment is more common among disadvantaged children than among non-disadvantaged ones. Appendix Figures A2 and A3 provide graphical illustrations of $A_{i}^{S}$ and $A_{i}^{E}$ for disadvantaged and non-disadvantaged eighth graders in the NABC. Compliance with the regulation is weaker in the first six months of the year than in the latter six months. Furthermore, the two months just after the cut-off date are characterized, on average, by early enrolment - a pattern, which is in line with the experience of other countries (see Puhani and Weber 2007 on Germany, for instance).

\section{B Why school starting age may matter for equality}

Prior to starting primary school, the overwhelming majority of Hungarian children go to kindergarten. Attendance is compulsory from age five, and over 95 percent of the five-year-olds and 99 percent of the six-year-olds are actually enrolled. Most children attend the district kindergarten closest to their home: a recent survey (Office of Education 2010) found that only 8.2 percent apply to kindergartens outside their own district. (This figure includes children who go to kindergartens closest to their parents' workplace). Furthermore, the study found no evidence of segregation by social background within the institutions under examination.

When children leave kindergarten, they enter one of the most segregated school systems of Europe. As shown in Jenkins et al. (2008), analysing PISA 2006, the impact of family background on test scores is nowhere as strong within the OECD as in Hungary. ${ }^{7}$ The same survey shows that Hungary has the highest ratio of between schools to total variance in student performance (OECD 2007). Furthermore, using TIMSS and PIRLS data, Csapó et al. (2009) demonstrate that a large part of what seems to be within-school variance at first sight comes from between-class and between-premises variance.

Large differences between schools and classes have evolved as a natural consequence of the laissezfaire regulations laid down at the fall of state socialism. Apart from a short period (2005 - 2009), children were allowed to apply to primary schools outside their districts, and schools were permitted

\footnotetext{
${ }^{6}$ Throughout the paper, delayed/early enrolment for reasons other than the date of birth will be referred to as "voluntary delayed/early enrolment".

7 Moreover, the percentage of variance in student performance explained by students' socio-economic background is the highest in Hungary within the PISA 2009 sample (OECD 2010, Vol. II, Figure 3.2).
} 
to admit children applying from elsewhere conditional on having admitted the local applicants. ${ }^{8}$ In the NABC population, 29 and 31 percent started primary school outside their own districts. Students are further screened at age 10 and 12 when around 3 and $4-5$ percent of them continue in eightand six-year academic secondary schools, respectively (Horn 2010). Schools are administered by more than 3,000 local governments in Hungary while the number of actual school districts (municipalities connected by daily commuting) hardly exceeds 150, the number of NUTS-4 regions. The fact that there is no responsible actor at the level of the genuine school districts makes efficient action against segregation difficult, if not impossible (Varga 2009).

The practice of routing disadvantaged children to segregated schools and classes affects the Roma minority disproportionately. (The share of Roma among the children of low-educated parents amounts to 37 percent according to Kertesi and Kézdi 2010). Havas and Liskó (2005) estimate that while there was a twofold increase in the share of Roma children in primary schools between 1980 and 2003, the number of 100 percent Roma classes grew by a factor of eight. Furthermore, they found the share of Roma children to be 30 percent in normal classes, 15 percent in special classes for high-achievers and 70 percent in special classes for low-achievers.

The children of low-educated parents have poor chance of attending better schools for several reasons: they start with an obvious handicap at the formal and informal entry examinations, their financial resources are insufficient to cover the costs of commuting to a distant school and bear the expenses of extracurricular activities customary in middle-class schools. Furthermore, many of them are discriminated on the basis of skin colour. Staying in the less segregated environment of the kindergarten for a further year potentially reduces their handicap, and helps them keep up with their schoolmates on top of the general (age-at-test, absolute and relative) age effects discussed earlier.

\section{Data}

For the empirical analysis, data is drawn from three different surveys (NABC, PIRLS, TIMSS) of students tested at the end of the academic year. To arrive at the working sample for each of the data sources, we include only those students who started school between the ages of six and seven. ${ }^{9}$ Excluding those who started school at an age younger than six or older than seven, amounts to dropping less than two percent of the samples. To distinguish between disadvantaged and nondisadvantaged subsamples, we use the mother's level of education, which is based on the International Standard Classification of Education (ISCED-97) in all datasets. The disadvantaged subsample consists of students whose mothers completed at most lower secondary education (ISCED2), which in Hungary amounts to completing eight years of primary school. The nondisadvantaged subsample consists of students whose mothers attained a tertiary degree (ISCED5 or ISCED6).

\footnotetext{
${ }^{8}$ In 2005 - 2009, the regulations tried to reduce schools' freedom of choice by putting a ban on formal entry exams and prescribing that priority should be given to children from the school's own district, in the first place, and socially disadvantaged children from other districts, in the second. Other applicants could be admitted on the basis of random draw. These regulations have been withdrawn by the government in office since April 2010.

${ }^{9}$ Estimation based on samples including all children independent of school starting age yields similar results.
} 


\section{A National Assessment of Basic Competencies (NABC), 2006}

The main results are based on the 2006 NABC, which covers all grade four and eight students in Hungary unless absent at the date of testing. ${ }^{10}$ The NABC sample is exceptionally large: we have about 80,000 observations at each grade level (after we arrive at our working sample). A further advantage of the dataset is that it includes information on both the exact date of birth and grade repetition. Consequently, actual school starting age can be computed accurately.

As the main dependent variable, we use a composite cognitive-academic test score. At the grade four level, the composite test score is the sum of five separate test scores: reading, writing, arithmetic, combinative thinking and analytical skills. Each of the five test scores falls to the range of $0-100$ points. At the grade eight level, the composite test score is the average of two test scores: literacy and mathematics. The average and standard deviation of the latter two tests is set at 500 and 100 points, respectively. As the range of the test scores differs between the two grades, we express the estimation results as the percentage of the standard deviation of the respective test scores.

The NABC contains a large set of background variables, which come from school and student questionnaires. Therefore, in addition to the specification where only the school starting age is used as a regressor (Specification 1), two alternative specifications are estimated. Specification 2 includes basic child, family, household and school level variables. Specification 3 includes seven additional controls for specific items in the Early Adolescent Home Observation for Measurement of the Environment (EA HOME) Inventory (Bradley et al. 2000) designed for the ages 10 to $15 .{ }^{11}$ Following Kertesi and Kézdi (2009), these seven control variables are chosen in order to capture the child's variety of experience, instructional activities and learning materials. Table 1 and Appendix Table A1 provide a list of the control variables for the different specifications and summary statistics, respectively.

The differences concerning test scores, family characteristics, home environment, learning materials and instructional activities follow the expected pattern: disadvantaged children attain lower test scores, have more siblings, have fewer educational resources at home, are less likely to participate in extra-curricular activities, read less often for enjoyment, spend less time with their families going to exhibitions, concerts and other cultural events, and their fathers have lower education levels. Although the expected school starting age is identical for the two subsamples, delayed school entry is slightly more common for disadvantaged children.

Note that as kindergarten attendance is measured on the category level (none, $0-1,1-2$ and more than 2 years), we can control for insufficient pre-school education but not for variation within the top category, which comprises the vast majority of children. Within the disadvantaged subsample of fourth graders, 76 percent spent more than two years in kindergarten while the respective share was 93 percent within the non-disadvantaged group. The differences by school starting age are minimal: 2.5 and 2.2 percentage points in the two subsamples, respectively, implying that our estimates of the

\footnotetext{
${ }^{10}$ See Kertesi and Kézdi (2010) for a detailed description of the NABC dataset.

${ }^{11}$ The HOME Inventory (first developed and used by Elardo et al. 1975) was designed to measure the quality and quantity of stimulation and support available to a child in the home environment. The EA HOME contains 60 items clustered into 7 subscales: (1) physical environment, (2) learning materials, (3) modelling, (4) instructional activities, (5) regulatory activities, (6) variety of experience and (7) acceptance and responsivity.
} 
effect of delayed start on academic performance are effectively uncontrolled for the duration of kindergarten attendance. ${ }^{12}$ Given that the overwhelming majority of children aged six and seven go to kindergarten, as previously mentioned, we can take it for granted that late starters had longer records of pre-school education than their counterparts with similar social background. Therefore, the estimated coefficients capture the effect of longer kindergarten attendance in addition to the age-at-test, absolute and relative age effects.

Table 1 Specifications and data sources

\begin{tabular}{lcl}
\hline Specification & Data source & \multicolumn{1}{c}{ Regressors } \\
\hline Specification 1 & NABC, 2006 & School starting age \\
Specification 2 NABC, 2006 & $\begin{array}{l}\text { School starting age, gender, years of kindergarten attendance, } \\
\text { living with both parents, number of siblings, father's education, } \\
\text { presence of computer at home, number of vacations in 2005, } \\
\text { number of books at home, child has books, class size, class size } \\
\text { squared, NUTS-3 region dummies at the school level }\end{array}$
\end{tabular}

Specification 3 NABC, 2006 Specification 2 plus family plays music / sings together, family goes to the cinema / theatre / concerts, family goes to exhibitions / museums, family discusses what happens in school, child attends extra-curricular activities, child's reading habits, child has a desk

Specification 4 PIRLS, 2001 School starting age, gender, index of early home literary activities, number of people living at home, father's education, presence of computer at home, family has a car, number of books at home, child has books

Specification 5 TIMSS, 2003 School starting age, gender, number of people living at home, father's education, presence of computer at home, family has a VCR, number of books at home

\section{B Progress in International Reading Literacy Study (PIRLS), 2001}

The second dataset used at the grade four level is the 2001 wave of the PIRLS, which is available for 35 countries. ${ }^{13}$ For the empirical analysis, data from the Student Questionnaire (which contains the reading test scores and basic student background information) and the Home Survey (which contains demographic and socio-economic indicators) are merged. The outcome variable is the reading score, which is standardized so that the mean is equal to 500 and the standard deviation equals 100 when all countries are weighted equally. The control variables included in the regression model (Specification 4) are similar to the variables in Specification 2 (NABC data) and are listed in Table 1.

\footnotetext{
${ }^{12}$ Within the disadvantaged subsample of fourth graders, 74.65 and 77.08 percent of those who started school at age six and age seven attended kindergarten for over two years, respectively. The corresponding figures for the non-disadvantaged subsample are 92.19 and 94.40 percent, respectively. For eighth graders the corresponding figures are 75.05 and 76.97 percent within the disadvantaged subsample, and 88.82 and 90.03 percent within the non-disadvantaged subsample, respectively.

${ }^{13}$ For an extensive description of the PIRLS dataset, testing procedure, scoring guide see Gonzalez and Kennedy (Eds.) (2003).
} 
Columns (1) and (2) of Table $A 3$ in the Appendix provide summary statistics, which confirm the picture outlined above based on the NABC data.

\section{C Trends in Mathematics and Science Study (TIMSS), 2003}

The third dataset used in the analysis is the 2003 wave of the TIMSS, which has been conducted in 48 countries at the grade four and eight levels. ${ }^{14} \mathrm{~A}$ drawback of the TIMSS data is that information on parental education is not available at the grade four level. Subsequently, we only use the eighth graders in our analysis. The outcome variable of interest is the mathematics score, the international mean of which is set at 500 and the standard deviation at 100. In the regression model, denoted as Specification 5, we use control variables similar to those in Specifications 2 (NABC) and 4 (PIRLS) (see Table 1). Columns (3) and (4) of Appendix Table A3 provide summary statistics of the variables used in the analysis, which differ by maternal education as expected.

\section{Estimation Results}

\section{A OLS versus IV estimates}

The OLS and IV estimation results for the full sample of students are reported in Table 2, expressed as percentage of the standard deviation of the full sample test score. The OLS estimate in the regression model without controls (Panel A, Column 1, Specification 1) indicates a negative correlation between actual school starting age and test score: the disadvantage of delayed enrolment amounts to around 22 percent of the standard deviation of the composite cognitiveacademic test score. With the inclusion of control variables, the OLS estimate decreases in absolute value.

The LATE coefficient estimate for Specification 1 (Panel B, Column 1) implies that delayed start increases the composite cognitive-academic test score by around 44 percent of the standard deviation. The finding that the OLS estimate is downward biased compared to the IV estimate is in line with the international literature analyzing grade four students. (See, for example, Bedard and Dhuey 2006 and Puhani and Weber 2007). A comparison of Specifications $1-3$ implies that the IV estimates are robust to the inclusion of additional covariates. Note that the F-statistics (Appendix Table A4, Panel A, Column 1) testing the significance of the instrument in the first-stage regressions exceed the threshold level of 10 (Staiger and Stock 1997, Stock et al. 2002) thus there is no indication of weak instruments.

At the grade eight level, the downward bias of the OLS estimate, the robustness of the IV estimate as well as instrument relevance are confirmed (see Table 2, Column 2 and Appendix Table A4, Panel B, Column 1$).{ }^{15}$

\footnotetext{
${ }^{14}$ For an extensive discussion of the TIMSS dataset, the content and cognitive domains tested for mathematics, the test design and scoring guide see Martin (Ed.) (2005).

${ }^{15}$ Note that the downward bias of the OLS estimate is confirmed in the subsample analysis at both grade levels. All estimation results available upon request.
} 


\begin{tabular}{lrrr}
\hline & A. OLS estimates & $\mathrm{N}=83425$ & $\mathrm{~N}=81236$ \\
Specification 1 & & $-\mathbf{2 2 . 0 3}$ & $-\mathbf{2 2 . 1 5}$ \\
Specification 2 & & $-\mathbf{7 . 2 6}$ & $-\mathbf{1 4 . 5 7}$ \\
Specification 3 & & $-\mathbf{7 . 1 9}$ & $-\mathbf{1 3 . 8 7}$ \\
& & & \\
Specification 1 & B. IV estimates & & \\
Specification 2 & & 44.16 & $\mathbf{2 7 . 3 5}$ \\
Specification 3 & & 41.28 & $\mathbf{2 6 . 1 8}$ \\
\hline
\end{tabular}

Notes Estimation results expressed as percentage of the standard deviation of the full sample test score. Bold figures are significant. The dependent variable is the composite cognitive-academic test score for all specifications and grade levels. Control variables for the different specifications are listed in Table 1.

\section{B IV estimates, subsample analysis}

Table 3 reports the IV estimates for subsamples of fourth and eighth graders distinguished by maternal education, expressed as the percentage of the standard deviation of the full sample test score.

The grade four LATE for disadvantaged children indicates a large positive effect of school starting age on academic performance, exceeding 80 percent of the standard deviation of the composite cognitive-academic test score for all specifications. Again, the inclusion of controls has little impact on the estimated age effect. The LATE estimates for children with highly educated mothers indicate that non-disadvantaged children who enter school a year later gain less from starting school later than their disadvantaged counterparts in grade four (around 27 percent of the standard deviation of the test score). The equality of the coefficient estimates across the two subsamples based on Specification 1 is rejected (see Appendix Table A5). Therefore, the estimation results support our key hypothesis that disadvantaged children have more to gain from starting school later than their nondisadvantaged counterparts.

Turning to grade eight, the LATE estimate for disadvantaged students remains statistically significant and large: around 35 percent of the standard deviation of the composite test score for the full specification (Specification 3). The conclusion that non-disadvantaged children gain less from starting school a year later in terms of academic competencies than their disadvantaged counterparts still holds, and the equality of the parameter estimates across the two subsamples can be rejected.

Comparing the magnitude of the grade four and eight results implies that the benefit of starting school at the age of seven instead of six fades as children progress through school. Note however that in the absence of longitudinal data, the comparison in time should be treated with caution. 


\begin{tabular}{lrrr}
\hline & A. Disadvantaged subsample & $\mathrm{N}=14973$ & $\mathrm{~N}=12332$ \\
Specification 1 & & $\mathbf{9 6 . 0 3}$ & $\mathbf{3 8 . 5 9}$ \\
Specification 2 & & $\mathbf{8 1 . 9 3}$ & $\mathbf{3 7 . 7 5}$ \\
Specification 3 & & $\mathbf{8 0 . 1 9}$ & $\mathbf{3 5 . 2 4}$ \\
& & & \\
Specification 1 & B. Non-disadvantaged subsample & $\mathrm{N}=16035$ & $\mathrm{~N}=17409$ \\
Specification 2 & & 26.25 & $\mathbf{2 1 . 3 8}$ \\
Specification 3 & & $\mathbf{2 7 . 6 3}$ & $\mathbf{1 9 . 7 9}$ \\
\hline
\end{tabular}

Notes Estimation results expressed as percentage of the standard deviation of the full sample test score. Bold figures are significant. The dependent variable is the composite cognitive-academic test score for all specifications and grade levels. Control variables for the different specifications are listed in Table 1.

\section{Sensitivity Analysis}

We check the sensitivity of our main result concerning between group differences in the age effect in four different ways: (1) using an alternative estimation approach, (2) estimating the test equation with two alternative outcome variables available in the NABC data, (3) using discontinuity samples and (4) carrying out the estimation using two alternative datasets, namely, the PIRLS and TIMSS.

\section{A Control function estimates}

As discussed above, we further analyse the data following the control function approach proposed in Garen (1984) to produce estimates of the ATE, which are reported in Table 4.

Starting with the grade four results (Column 1), the ATE estimates are positive and statistically significant for disadvantaged children and statistically insignificant for non-disadvantaged ones. For both subsamples, the ATE estimates are lower than the corresponding LATE estimates. At the grade eight level (Column 2), the ATE estimates still imply a statistically significant benefit to starting school later for the average disadvantaged child, which is smaller in magnitude than in grade four. The benefit amounts to 42 and 16 percent of the standard deviation of the full sample composite academic-competencies test scores in grades four and eight, respectively. The ATE estimates for both subgroups are below the corresponding LATE estimates.

Overall, although smaller in magnitude, the ATE estimates confirm the LATE estimates along two lines. First, disadvantaged children have more to gain from starting school later than their nondisadvantaged counterparts in both grades. Second, the advantage of delayed enrolment seems to decrease as disadvantaged children progress through school. A comparison of the magnitudes of the LATE and corresponding ATE estimates suggests a negative selection into voluntary delayed enrolment. 


\begin{tabular}{lcrr}
\hline & A. Full sample & $\mathrm{N}=83425$ & $\mathrm{~N}=81236$ \\
Specification 1 & & 2.52 & $\mathbf{1 0 . 3 8}$ \\
Specification 2 & & 16.34 & $\mathbf{1 4 . 1 2}$ \\
Specification 3 & & $\mathbf{1 5 . 3 1}$ & $\mathbf{1 4 . 5 2}$ \\
& & & \\
Specification 1 & B. Disadvantaged subsample & $\mathrm{N}=14973$ & $\mathrm{~N}=12332$ \\
Specification 2 & & $\mathbf{3 3 . 2 6}$ & 12.67 \\
Specification 3 & & $\mathbf{4 6 . 1 5}$ & $\mathbf{1 8 . 5 5}$ \\
& & $\mathbf{4 2 . 1 0}$ & $\mathbf{1 5 . 8 8}$ \\
Specification 1 & C. Non-disadvantaged subsample & & \\
Specification 2 & & $\mathrm{N}=16035$ & $\mathrm{~N}=17409$ \\
Specification 3 & & 0.40 & 10.56 \\
\hline
\end{tabular}

Notes Estimation results expressed as percentage of the standard deviation of the full sample test score. Bold figures are significant. Standard errors are computed by 500 bootstrap replications. The dependent variable is the composite cognitive-academic test score for all specifications and grade levels. Control variables for the different specifications are listed in Table 1.

\section{B Mathematics and reading test scores}

As a further robustness check, we separate the composite test scores into literacy and mathematics components, and use the latter two measures as dependent variables. More specifically, the grade four "reading test score" is the sum of the reading and writing test scores, and the "mathematics test score" is sum of the test scores for arithmetic, combinative thinking and analytical skills. At grade eight, we simply use the original test scores for reading and mathematics.

The estimation results are presented in Table 5. First of all, note that school starting age has a significant effect on both reading and mathematics test scores in both grades for both subsamples. For disadvantaged children, we see a large benefit of delayed primary school enrolment in grade four, exceeding 84 and 35 percent of the standard deviation of the mathematics and reading tests, respectively. Whereas their benefit fades substantially by grade eight in terms of mathematics, it remains relatively stable across the two grades in terms of reading. The latter result also holds for the non-disadvantaged subsample.

Although our key hypothesis is confirmed by the estimation results, it must be pointed out, that in grade eight the benefit of delayed enrolment in terms of mathematical competencies is only slightly higher for disadvantaged children, as opposed to reading. 
Table 5 IV estimation results, NABC, mathematics and reading scores as dependent variables

Grade $4 \quad$ Grade 8

(1)

\begin{tabular}{|c|c|c|}
\hline A. Full sample & $\mathrm{N}=83425$ & $\mathrm{~N}=81236$ \\
\hline Specification 1, mathematics score & 44.27 & 22.61 \\
\hline Specification 2, mathematics score & 41.76 & 21.38 \\
\hline Specification 3, mathematics score & 40.48 & 21.35 \\
\hline Specification 1 , reading score & 24.73 & 27.93 \\
\hline Specification 2, reading score & 22.19 & 27.00 \\
\hline Specification 3 , reading score & 21.81 & 27.29 \\
\hline B. Disadvantaged subsample & $N=14973$ & $N=12332$ \\
\hline Specification 1, mathematics score & 95.89 & 27.63 \\
\hline Specification 2, mathematics score & 85.37 & 26.13 \\
\hline Specification 3, mathematics score & 84.05 & 23.52 \\
\hline Specification 1 , reading score & 54.77 & 43.75 \\
\hline Specification 2 , reading score & 37.87 & 43.70 \\
\hline Specification 3, reading score & 35.83 & 41.67 \\
\hline C. Non-disadvantaged subsample & $N=16035$ & $N=17409$ \\
\hline Specification 1, mathematics score & 24.40 & 19.37 \\
\hline Specification 2, mathematics score & 26.67 & 17.67 \\
\hline Specification 3, mathematics score & 26.30 & 19.18 \\
\hline Specification 1 , reading score & 19.49 & 20.13 \\
\hline Specification 2, reading score & 18.03 & 18.89 \\
\hline Specification 3 , reading score & 17.49 & 21.35 \\
\hline
\end{tabular}

Notes Estimation results expressed as percentage of the standard deviation of the full sample test score. Bold figures are significant. Control variables for the different specifications are listed in Table 1.

\section{C Discontinuity samples}

A common critique of using expected school starting age as an instrument is the possible direct effect of month of birth on educational outcomes, which would invalidate the instrument, as argued in Bound et al. (1995) and Bound and Jaeger (2000) among others. ${ }^{16}$ In order to check the robustness of the results for the subsamples, we use discontinuity samples (as for example Elder and Lubotsky 2009, Puhani and Weber 2007, Strøm 2004) i.e. subsamples of students born two months before and after the cut-off date. Using discontinuity samples has the advantage that (a) the possibility of birth timing is limited and (b) even if month of birth directly affects test scores, this association will not lead to bias as long as the children born close to the cut-off date are similar in unobservable characteristics (Elder and Lubotsky 2008). The four-month window is chosen to assure enough

\footnotetext{
${ }^{16}$ The non-randomness of the month of birth cannot be considered an established result. For instance, Angrist and Kruger (1992) cite studies providing opposing evidence: one concluding that "genetic-season-of birth effect exists because genetically inferior individuals are less able to contain their sexual passions in the summer", and an opposing one claiming that "the seasonal pattern of children's birth is unrelated to the wealth and marital status of their parents".
} 
observations for subsample analysis. The results based on the discontinuity samples for fourth and eighth graders are reported in Table 6. Despite the relatively large sample sizes (ranging between 4,126 and 5,936), the coefficients are generally less precisely estimated than those reported for the full subsample, as we are only using about one third of the observations. Note that in the discontinuity samples the instrument is still strong enough ( $F$-statistic is larger than the threshold value of 10 as shown in Table A4 of the Appendix). The general conclusions drawn based on the discontinuity sample estimates remain identical to those based on the full sample: disadvantaged children gain more from delayed primary school enrolment than their non-disadvantaged counterparts, but the benefit is smaller in grade eight.

Table 6 IV estimation results, NABC, discontinuity samples: born April - July

\begin{tabular}{lrrr}
\hline & & Grade 4 & \multicolumn{2}{c}{ Grade 8 } \\
& & \multicolumn{1}{c}{$(1)$} & \multicolumn{1}{c}{$(2)$} \\
\hline & A. Full sample & $\mathrm{N}=26775$ & $\mathrm{~N}=27313$ \\
Specification 1 & & 34.00 & $\mathbf{2 5 . 4 7}$ \\
Specification 2 & & 32.37 & $\mathbf{2 4 . 7 8}$ \\
Specification 3 & & 32.37 & $\mathbf{2 5 . 5 0}$ \\
& & & \\
Specification 1 & B. Disadvantaged subsample & $\mathrm{N}=4879$ & $\mathrm{~N}=4126$ \\
Specification 2 & & 51.49 & $\mathbf{3 8 . 9 9}$ \\
Specification 3 & & 46.56 & $\mathbf{3 7 . 9 7}$ \\
& & 47.20 & $\mathbf{3 5 . 8 8}$ \\
Specification 1 & C. Non-disadvantaged subsample & & \\
Specification 2 & & $\mathrm{N}=5132$ & $\mathrm{~N}=5936$ \\
Specification 3 & & $\mathbf{2 5 . 7 1}$ & 13.60 \\
\hline
\end{tabular}

Notes Estimation results expressed as percentage of the standard deviation of the full sample test score. Bold figures are significant. The dependent variable is the composite cognitive-academic test score for all specifications and grade levels. Control variables for the different specifications are listed in Table 1.

\section{D PIRLS and TIMSS data}

As a final robustness check, the regression analysis is carried out using the widely used datasets in the existing international studies. The estimation results based on the PIRLS and TIMSS data are reported in Table 7. The coefficient estimates, although four out of six are statistically insignificant because of the small sample sizes, are in line with the estimation results based on the NABC dataset: those estimated for disadvantaged students are larger than those for non-disadvantaged children. To put the Hungarian estimates into perspective, note that the LATE estimate for German grade four students based on the PIRLS data is around 40 percent of the standard deviation of the test score (in Puhani and Weber 2007). Furthermore, Bedard and Dhuey (2006) find statistically significant LATE for a number of OECD countries based on the TIMSS data, ranging from around 13 percent to around 35 
percent of the international standard deviation of the mathematics test score for the full sample of grade eight students in Italy and New Zealand respectively. ${ }^{17}$

Table 7 PIRLS and TIMSS results

LATE

A. PIRLS, grade four

Specification 4, Full sample, $N=4452$

Specification 4, Disadvantaged subsample, $N=729$

Specification 4, Non-disadvantaged subsample, $\mathrm{N}=926$

B. TIMSS, grade eight

Specification 5, Full sample, $N=3158$

Specification 5, Disadvantaged subsample, $\mathrm{N}=430$

Specification 5, Non-disadvantaged subsample, $N=784$

Notes Estimation results expressed as percentage of the standard deviation of the full sample test score. Bold figures are significant. The dependent variable is the reading and mathematics test score with the PIRLS and TIMSS data, respectively. Control variables for the different specifications are listed in Table 1.

\section{Closing remarks}

We found that low-status children gain significantly more from starting school later than their highstatus counterparts, and this result proved to be robust to changes in the method of estimation, field of testing, choice of sample and data. The finding that late starters generally gain is not new and can be potentially explained by the facts that they are older at testing, more productive in attaining a curriculum geared at the average child and older than their classmates at any point in time. However, these mechanisms do not seem to explain the sizeable between group differences found in our data. The higher efficiency of kindergartens in developing the relative skills of low-status children appears to us as the only plausible explanation of why late starters perform much better within the lowstatus group, and why their advantage decreases over time.

Such an explanation is consistent with the findings of education research. While the Hungarian school system follows the 'Prussian tradition' in being curriculum-oriented and responding to those falling behind by punishment, segregation and exclusion (routing to class repetition, directing the laggards to special classes and less demanding schools), kindergartens put stronger emphasis on the development of basic competencies and do so in a playful and more cooperative environment. (See a general overview in Nagy 2009). ${ }^{18}$ We think that our results are indicative of this contrast, and call for more inclusive and less segregated education in the primary school.

\footnotetext{
17 The standard deviation for the Hungarian samples of the PIRLS and TIMSS is lower than the standard deviation in the German sample of the PIRLS and international TIMSS data thus the difference between the estimates based on the latter data and the Hungarian one is larger when expressed as percentage of the standard deviation.

${ }^{18}$ The comprehensive kindergarten network came into being much later than the school system and its program was strongly influenced by the Montessori method.
} 


\section{References}

Angrist JD (2004) Treatment Effect Heterogeneity in Theory and Practice. The Economic Journal 114 (494), C52-C83.

Angrist JD, Kruger AB (1992) The effect of age at school entry on education attainment: An application of instrumental variables with moments from two samples. Journal of the American Statistical Association 87(418), 979 - 1014.

Angrist JD, Pischke J-S (2009) Mostly Harmless Econometrics: An Empiricist's Companion. New Jersey: Princeton University Press.

Bedard K, Dhuey E (2006) The Persistence of Early Childhood Maturity: International Evidence of Long-Run Age Effects. The Quarterly Journal of Economics 121(4), 1437 - 1472.

Bertschy K, Cattaneo MA, Wolter SC (2009) PISA and the Transition into the Labour Market. LABOUR: Review of Labour Economics and Industrial Relations 23, 111- 117.

Bound J, Jaeger DA, Baker MA (1995) Problems with Instrumental Variables Estimation When the Correlation Between the Instruments and the Endogenous Explanatory Variable is Weak. Journal of the American Statistical Association 90(430), 443-450.

Bound J, Jaeger DA (2000) Do compulsory school attendance laws alone explain the association between earnings and quarter of birth? Research in Labor Economics 19, 83- 108.

Black SE, Devreux P, Salvanes KG (2008) Too Young to Leave the Nest? The Effects of School Starting Age. NBER Working Paper 13969.

Bradley RH, Corwyn RF, Caldwell BM, Whiteside-Mansell L, Wasserman GA, Mink IT (2000) Measuring the Home Environments of Children in Early Adolescence. Journal of Research on Adolescence 10(3), $247-288$.

Card D (1999) The causal effect of education on earnings. In: O Ashenfelter and D Card (Eds.), Handbook of Labor Economics 3, Chapter 30 (pp. 1801 - 1863). Amsterdam: Elsevier.

Card D (2001) Estimating the Returns to Schooling: Progress on Some Persistent Econometric Problems. Econometrica 69(5), $1127-1160$.

Cascio E, Schanzenbach DW (2007) First in the Class? Age and the Education Production Function. NBER Working Paper 13663.

Csapó B, Molnár Gy, Kinyó L (2009) A magyar oktatási rendszer szelektivitása a nemzetközi vizsgálatok tükrében [Analysis of the Selectiveness of the Hungarian Educational System in International Context]. Iskolakultúra 4, 3-13.

Datar A (2006) Does delaying kindergarten entrance give children a head start? Economics of Education Review 25, $43-62$.

Dobkin C, Ferreira F (2010) Do school entry laws affect educational attainment and labor market outcomes? Economics of Education Review 29, 40 - 54.

Elardo R, Bradley R, Caldwell BM (1975) The relation of infants' home environments to mental test performance from six to thirty-six months: A longitudinal analysis. Child Development 46, $71-$ 76.

Elder TE, Lubotsky DH (2008) Kindergarten Entrance Age and Children's Achievement: Impacts of State Policies, Family Background, and Peers. The Journal of Human Resources 44(3), 641 683.

Fertig M, Kluve J (2005) The Effect of Age at School Entry on Educational Attainment in Germany. IZA Discussion Paper No. 1507.

Fredrikkson P, Öckert B (2005) Is Early Learning really More Productive? The Effect of School Starting Age on School and Labor Market Performance. IZA Discussion Paper No. 1659.

Garen J (1984) The returns to schooling: a selectivity bias approach with a continuous choice variable. Econometrica 52, $1199-1218$.

Gonzalez EJ, Kennedy MA (Eds.) (2003) PIRLS 2001 User Guide for the International Data-base. International Study Center, Lynch School of Education, Boston College. 
Havas G (2008) Equality of opportunity, desegregation. In: K Fazekas, J Köllő and J Varga (Eds.), Green Book for the Renewal of Public Education in Hungary (pp. 131 - 149). Budapest: Ecostat.

Havas G, Liskó I (2006) Óvodától a szakmáig [From kindergarten to professional education]. Budapest: Oktatáskutató Intézet - Új Mandátum.

Hámori Sz (2008) The Effect of School Starting Age on Academic Performance in Hungary. CDSE Discussion Paper No. 34.

Horn (2010) A kisgimnáziumok szerepe a szelekcióban [Role of the early selective tracks in educational selection]. In: T Kolos and IGY Tóth (Eds.), Társadalmi Riport 2010 (pp. 408 - 429). Budapest: TÁRKI.

Imbens GW, Angrist JD (1994) Identification and Estimation of Local Average Treatment Effects. Econometrica 62(2), $467-475$.

Jenkins SP, Micklewright J, Schnepf SV (2008) Social Segregation in Secondary Schools: How Does England Compare with Other Countries? Oxford Review of Education 34(1), $21-38$.

Kemény I, Janky B, Lengyel G (2004) A magyarországi cigányság, 1971-2003 [The Roma population in Hungary]. Budapest: Gondolat Kiadó - MTA Etnikai-nemzeti Kisebbségkutató Intézet.

Kertesi G, Kézdi G (2010) Segregation of Primary Schools in Hungary. A Descriptive Study Using Data from the National Assessment of Basic Competencies of 2006. In: K Fazekas, A Lovász and Á Telegdy (Eds.), The Hungarian Labour Market 2010 (pp. 99 - 119). Budapest: IE HAS, Hungarian Employment Foundation.

Kertesi G, Kézdi G (2009) Iskoláskor előtti egyenlőtlenségek [Pre-primary school inequality]. In: K Fazekas (Ed.), Oktatás és foglalkoztatás (pp. 107 -121). Budapest: IE HAS.

Kertesi G, Kézdi G (2005) Általános iskolai szegregáció - Okok és következmények [Segregation in primary education. Causes and Consequences]. Közgazdasági Szemle 52 (4-5), 317-356, 462480.

Köllő J (2008) Employment policy measures to promote education reforms. In: K Fazekas, J Köllő and J Varga (Eds.), Green Book for the Renewal of Public Education in Hungary (pp. 269 - 283). Budapest: Ecostat.

Leuven $E$, Lindhal M, Oosterbeek H, Webbnik D (2010) Expanding schooling opportunities for 4-yearolds. Economics of Education Review 29, $319-328$.

Martin MO (Ed.) (2005) TIMSS 2003 User Guide for the International Database. TIMSS \& PIRLS International Study Center, Lynch School of Education, Boston College.

McEwan PJ, Shapiro JS (2007) The Benefits of Delayed Primary School Enrollment: Discontinuity Estimates Using Exact Birth Dates. The Journal of Human Resources 43(1), 1- 29.

Nagy J (2008) Renewing primary educatrion. In: K Fazekas, J Köllő and J Varga (Eds.), Green Book for the Renewal of Public Education in Hungary (pp. $61-80)$. Budapest: Ecostat.

OECD (2007) PISA 2006 Science competencies for tomorrow's world. Paris: OECD.

OECD (2010) PISA 2009 Results: Overcoming Social Background: Equity in Learning Opportunities and Outcomes (Volume II). Paris: OECD.

Office of Education (2010) Összegző jelentés az esélyegyenlőségi projekt keretében szervezett, egyenlő bánásmód követelményének érvényesülésére irányuló hatósági ellenőrzés tapasztalatairól - kiemelten az óvodai felvételek és a gyermekek csoportba sorolása tekintetében. [Summary report of the equal opportunity project - with a focus on kindergarten enrolment and the segregation of children within institutions] Budapest: Office of Education.

Puhani PA, Weber AM (2007) Does the Early Bird Catch the Worm? Instrumental Variable Estimates of Educational Effects of Age of School Entry in Germany. Empirical Economics 32, 359- 386.

Staiger D, Stock HJ (1997) Instrumental Variables Regression with Weak Instruments. Econometrica 65(3), $557-586$.

Stock JH, Wright JH, Yogo M (2002) Survey of Weak Instruments and Weak Identification in Generalized Method of Moments. Journal of Business and Economic Statistics 4(20), 518 - 529. 
Strøm B (2004) Student Achievement and Birthday Effects. CESifo / PEPG Schooling and Human Capital Formation in the Global Economy. CESifo Conference Center.

Varga J (2009) Institutional structure and funding in education. In: K Fazekas, J Köllö and J Varga (Eds.), Green Book for the Renewal of Public Education in Hungary (pp. 245 - 268). Budapest: Ecostat. 


\section{Appendix}

\section{A The Hungarian education system}

Figure A1 The Hungarian education system

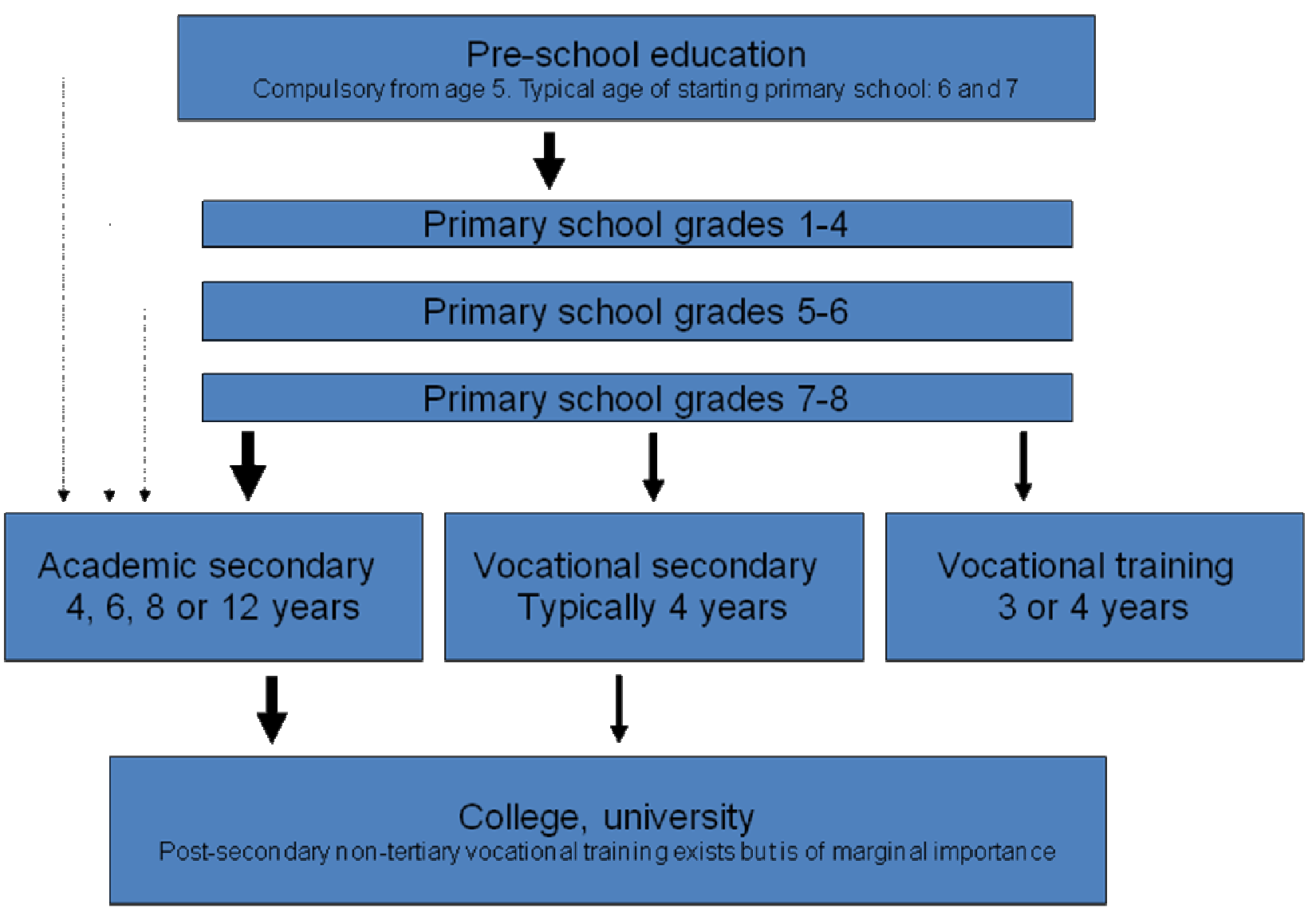

Notes: A secondary school leaving exam is required for those applying to higher education. Vocational training schools do not prepare their students for the secondary school leaving exam, but their graduates can participate in preparatory courses voluntarily. 


\section{B Enrolment patterns}

Figure A2 Average actual school starting age versus average expected school starting age, disadvantaged children, grade eight

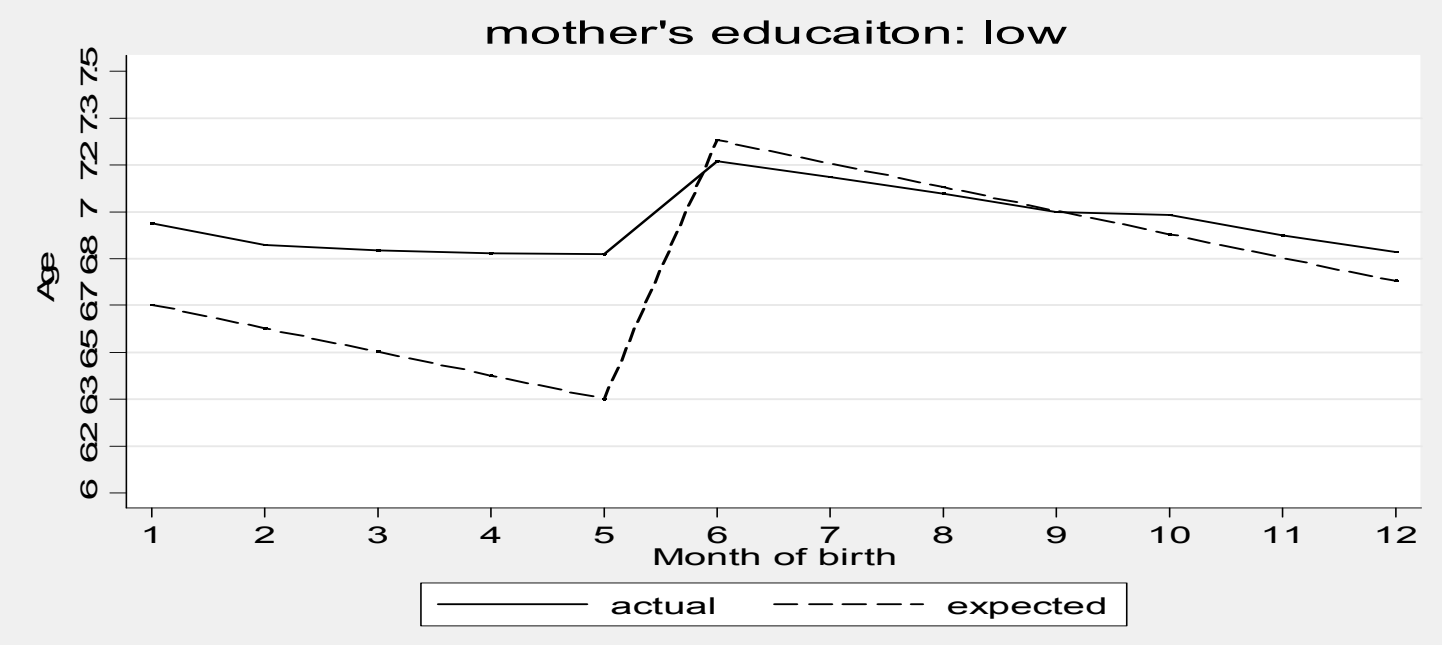

Figure A3 Average actual school starting age versus average expected school starting age, nondisadvantaged children, grade eight

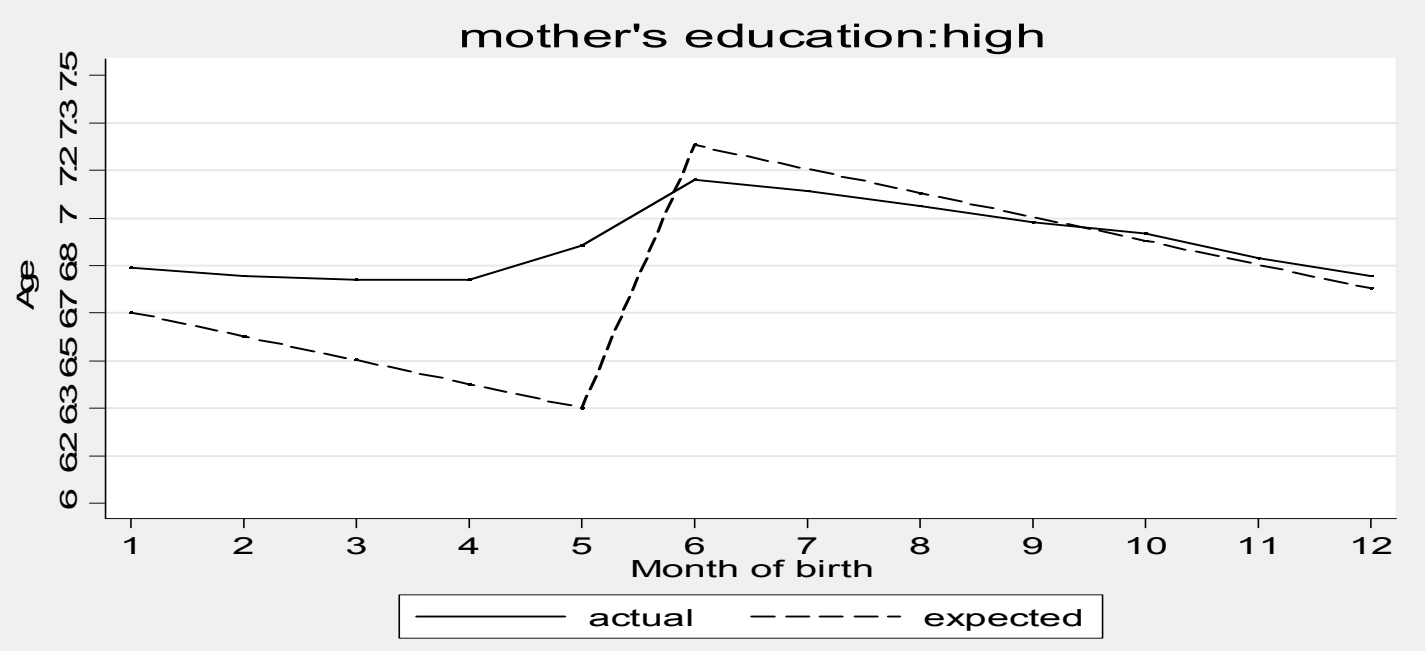


Table A1 Enrolment patterns (percent)

Full sample $\quad \begin{gathered}\text { Disadvantaged } \\ \text { subsample }\end{gathered}$
subs

(1)
(2)

A. Grade 4, NABC (2006), primary school enrolment in 2002

According to regulation: age of six

According to regulation: age of seven

Voluntary early enrolment

Voluntary delayed enrolment
45.82

33.74

1.20

19.25

40.13

33.25

48.19

33.51

1.76

16.53

B. Grade 8, NABC (2006), primary school enrolment in 1998

According to regulation: age of six

51.13

47.83

51.61

According to regulation: age of seven

33.14

33.44

1.60

1.31

32.49

Voluntary early enrolment

14.13

17.42

2.27

13.63

C. PIRLS (2001), primary school enrolment in 1997

According to regulation: age of six

52.11

46.09

54.43

According to regulation: age of seven

31.38

29.22

1.75

1.92

31.43

Voluntary early enrolment

14.76

22.77

2.27

11.88

D. TIMSS (2003), primary school enrolment in 1995

According to regulation: age of six

52.82

45.35

55.36

According to regulation: age of seven

32.01

35.12

Voluntary early enrolment

1.84

1.16

29.85

Voluntary delayed enrolment

13.33

18.37 


\section{Descriptive statistics}

Table A2 Descriptive Statistics, NABC

\begin{tabular}{|c|c|c|c|c|}
\hline & \multicolumn{2}{|c|}{ Grade 4} & \multicolumn{2}{|c|}{ Grade 8} \\
\hline & $(1)$ & $(2)$ & $(3)$ & $(4)$ \\
\hline \multirow[t]{2}{*}{ Mean test score: reading } & 137.87 & 149.83 & 443.94 & 562.88 \\
\hline & $(23.34)$ & $(20.09)$ & $(87.33)$ & $(90.41)$ \\
\hline \multirow[t]{2}{*}{ Mean test score: mathematics } & 127.32 & 187.69 & 436.94 & 561.62 \\
\hline & $(45.12)$ & $(54.04)$ & $(83.66)$ & $(96.92)$ \\
\hline \multirow[t]{2}{*}{ Mean test score: composite cognitive-academic skills } & 265.20 & 337.52 & 440.44 & 562.25 \\
\hline & $(59.34)$ & $(64.44)$ & $(77.75)$ & (84.89) \\
\hline Gender: Male & 47.31 & 50.08 & 43.28 & 48.95 \\
\hline Gender: Female & 52.69 & 49.92 & 56.71 & 51.04 \\
\hline Gender: Missing & 0.00 & 0.00 & 0.01 & 0.01 \\
\hline Years attended kindergarten: Zero & 0.61 & 0.14 & 0.67 & 0.30 \\
\hline Years attended kindergarten: At most one & 6.56 & 1.59 & 6.65 & 2.10 \\
\hline Years attended kindergarten: Between one and two & 16.20 & 4.75 & 14.75 & 7.09 \\
\hline Years attended kindergarten: More than two & 76.04 & 93.30 & 76.98 & 90.00 \\
\hline Years attended kindergarten: Missing & 0.59 & 0.22 & 0.95 & 0.51 \\
\hline Child lives with both parents: Yes & 70.51 & 80.24 & 68.25 & 75.64 \\
\hline Child lives with both parents: No & 27.40 & 19.38 & 30.76 & 24.13 \\
\hline Child lives with both parents: Missing & 2.09 & 0.38 & 1.00 & 0.23 \\
\hline Number of siblings: Zero & 6.83 & 14.53 & 6.34 & 13.01 \\
\hline Number of siblings: One & 23.38 & 50.39 & 27.73 & 52.70 \\
\hline Number of siblings: Two & 30.02 & 23.67 & 31.72 & 23.39 \\
\hline Number of siblings: Three & 16.73 & 6.92 & 16.72 & 6.61 \\
\hline Number of siblings: More than three & 21.39 & 3.75 & 16.23 & 3.63 \\
\hline Number of siblings: Missing & 1.66 & 0.73 & 1.26 & 0.66 \\
\hline Father's education: At most eight years of primary school & 47.41 & 0.89 & 37.33 & 0.76 \\
\hline Father's education: Vocational degree & 40.28 & 16.09 & 48.24 & 16.77 \\
\hline Father's education: Secondary school degree & 5.36 & 26.35 & 6.71 & 25.77 \\
\hline Father's education: Tertiary degree & 1.18 & 54.82 & 1.14 & 54.56 \\
\hline Father's education: Missing & 5.77 & 1.85 & 6.58 & 2.14 \\
\hline Presence of computer at home: Yes & 45.88 & 95.30 & 58.32 & 96.97 \\
\hline Presence of computer at home: No & 40.90 & 3.27 & 37.83 & 1.83 \\
\hline Presence of computer at home: Missing & 13.22 & 1.43 & 3.85 & 1.20 \\
\hline Number of vacations in the past year: Zero & 38.54 & 5.21 & 29.98 & 6.07 \\
\hline Number of vacations in the past year: One & 25.26 & 19.71 & 26.73 & 20.78 \\
\hline Number of vacations in the past year: Two & 15.46 & 26.62 & 20.25 & 28.20 \\
\hline Number of vacations in the past year: Three or more & 17.71 & 46.96 & 21.21 & 43.48 \\
\hline Number of vacations in the past year: Missing & 3.03 & 1.50 & 1.83 & 1.47 \\
\hline Number of books at home: Less than 50 & 43.41 & 0.68 & 34.62 & 0.59 \\
\hline Number of books at home: Around 50 & 23.11 & 1.77 & 24.51 & 1.54 \\
\hline Number of books at home: $51-150$ & 18.16 & 9.94 & 22.71 & 9.40 \\
\hline Number of books at home: $151-300$ & 5.93 & 16.33 & 8.77 & 15.41 \\
\hline Number of books at home: $301-600$ & 2.77 & 24.71 & 4.05 & 22.99 \\
\hline Number of books at home: $601-1000$ & 1.18 & 24.43 & 2.22 & 24.77 \\
\hline Number of books at home: More than 1000 & 0.73 & 21.49 & 1.13 & 24.57 \\
\hline Number of books at home: Missing & 4.72 & 0.65 & 1.99 & 0.74 \\
\hline Child has books: Yes & 85.27 & 99.35 & 86.59 & 98.78 \\
\hline Child has books: No & 10.29 & 0.28 & 11.65 & 0.79 \\
\hline Child has books: Missing & 4.44 & 0.37 & 1.76 & 0.43 \\
\hline
\end{tabular}


Class size

Family plays music / sings together: Yes

Family plays music / sings together: No

Family plays music / sings together: Missing

Family goes to the cinema / theatre / concerts: Yes

Family goes to the cinema / theatre/ concerts: No

Family goes to the cinema / theatre/ concerts: Missing

Family goes to exhibitions / museums: Yes

Family goes to exhibitions / museums: No

Family goes to exhibitions / museums: Missing

Family discusses daily / almost daily what happens in

school: Yes

Family discusses daily / almost daily what happens in

school: No

Family discusses daily / almost daily what happens in

school: Missing

Child attends extra-curricular activities: Yes

Child attends extra-curricular activities: No

Child attends extra-curricular activities: Missing

Child's reading habits: Currently reads something for

enjoyment

Child's reading habits: Last time read something for

enjoyment was last month

Child's reading habits: Last time read something for

enjoyment was during this academic year

Child's reading habits: Used to read for enjoyment

Child's reading habits: Never read anything for enjoyment

Child's reading habits: Missing

Child has a desk: Yes

Child has a desk: No

Child has a desk: Missing

Mean Actual school starting age ${ }^{a}$

Mean expected school starting age ${ }^{a}$

Sample size

the subsample of fourth graders with high-educated mothers, Column

graders with low-educated mothers and Column (4) refers to the subsample of eighth graders with higheducated mothers, whereby low and high education correspond to at most eight years of primary school and to tertiary degree respectively. Standard deviations are in parentheses for continuous variables. ${ }^{\text {a }}$ School starting age measured in years.

\begin{tabular}{|c|c|c|c|}
\hline \multicolumn{4}{|c|}{ Table A2 continued } \\
\hline 19.96 & 24.15 & 20.93 & 25.41 \\
\hline 58.88 & 64.08 & 49.76 & 43.24 \\
\hline 31.72 & 33.76 & 46.52 & 54.59 \\
\hline 9.40 & 2.16 & 3.72 & 2.17 \\
\hline 30.43 & 76.07 & 37.51 & 72.54 \\
\hline 60.02 & 21.76 & 59.28 & 25.55 \\
\hline 9.55 & 2.17 & 3.20 & 1.91 \\
\hline 18.75 & 64.53 & 18.47 & 55.29 \\
\hline 70.36 & 33.00 & 77.82 & 42.34 \\
\hline 10.89 & 2.47 & 3.71 & 2.37 \\
\hline 68.50 & 88.44 & 54.72 & 72.04 \\
\hline 25.27 & 10.22 & 42.83 & 26.58 \\
\hline 6.23 & 1.34 & 2.45 & 1.38 \\
\hline 39.33 & 77.72 & 41.32 & 73.08 \\
\hline 52.21 & 20.84 & 55.34 & 25.48 \\
\hline 8.46 & 1.43 & 3.34 & 1.44 \\
\hline 28.89 & 60.52 & 18.85 & 47.47 \\
\hline 24.42 & 19.38 & 22.17 & 22.30 \\
\hline 24.54 & 14.04 & 26.57 & 18.03 \\
\hline 10.67 & 3.47 & 19.45 & 8.47 \\
\hline 9.15 & 1.80 & 11.77 & 2.84 \\
\hline 2.34 & 0.79 & 1.20 & 0.88 \\
\hline 73.68 & 96.36 & 81.65 & 97.66 \\
\hline 20.95 & 3.15 & 16.79 & 1.87 \\
\hline 5.37 & 0.49 & 1.57 & 0.47 \\
\hline $5(0.38)$ & $6.95(0.35)$ & $6.96(0.37)$ & $6.91(0.35)$ \\
\hline O (0.29) & $6.80(0.28)$ & $6.80(0.29)$ & $6.80(0.29)$ \\
\hline 14973 & 16035 & 12332 & 17409 \\
\hline
\end{tabular}

ted mothers, Column (2) refers to 


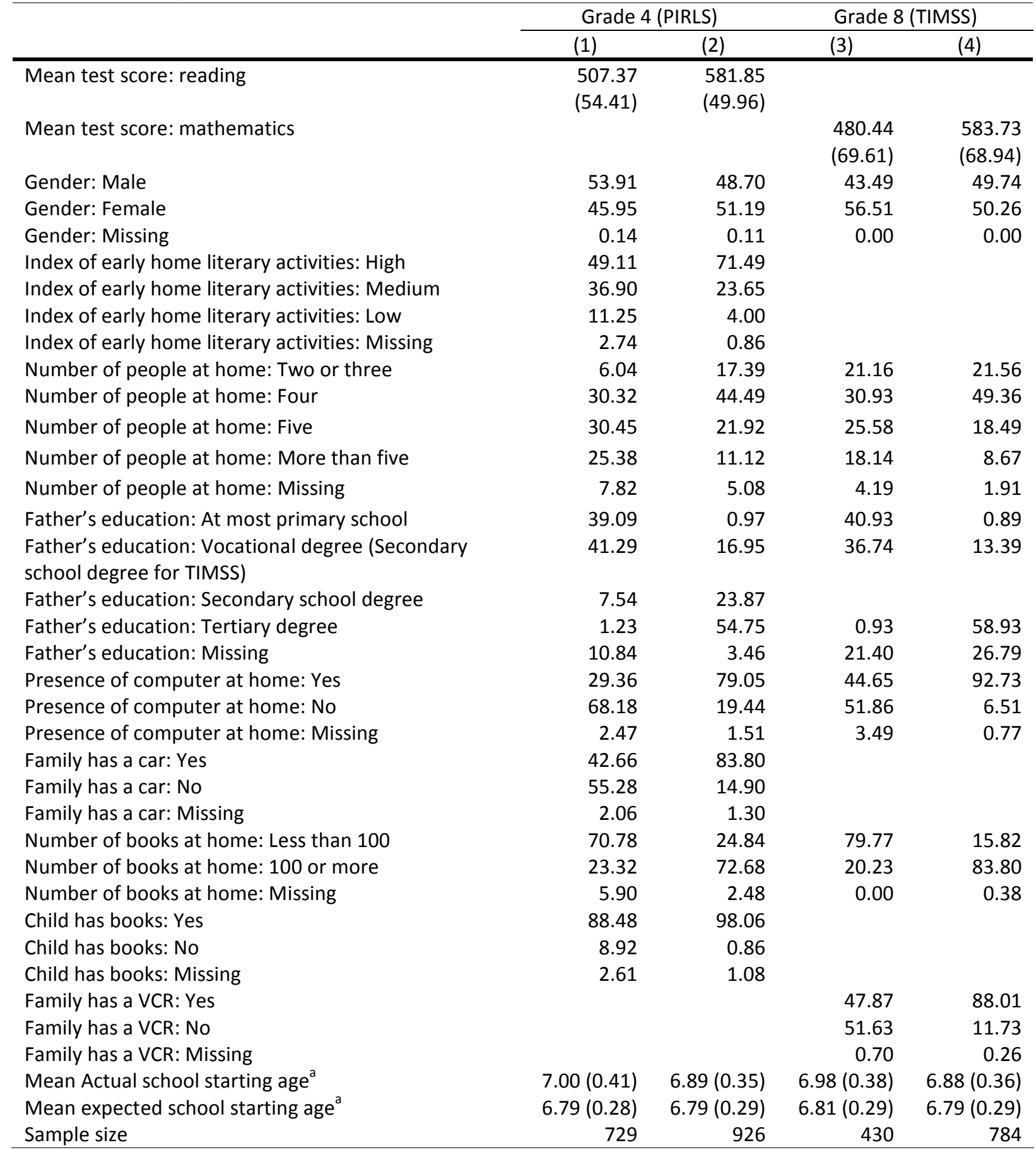

Notes Column (1) refers to the subsample of fourth graders with low-educated mothers (PIRLS data), Column (2) refers to the subsample of fourth graders with high-educated mothers (PIRLS data), Column (3) refers to the subsample of eighth graders with low-educated mothers (TIMSS data) and Column (4) refers to the subsample of eighth graders with high-educated mothers (TIMSS data), whereby low and high education correspond to at most eight years of primary school and to tertiary degree respectively. Standard deviations are in parentheses for continuous variables. ${ }^{\text {a }}$ School starting age measured in years. 


\section{Statistical tests}

Table A4 First-stage results, Specification 1

\begin{tabular}{|c|c|c|c|c|c|c|}
\hline & Full sample & $\begin{array}{l}\text { Disadvantaged } \\
\text { subsample }\end{array}$ & $\begin{array}{l}\text { Non- } \\
\text { disadvantaged } \\
\text { subsample }\end{array}$ & $\begin{array}{l}\text { Discontinuity } \\
\text { sample }\end{array}$ & $\begin{array}{l}\text { Discontinuity } \\
\text { sample, } \\
\text { disadvantaged } \\
\text { subsample } \\
\text { (5) }\end{array}$ & $\begin{array}{l}\text { Discontinuity } \\
\text { sample, } \\
\text { non- } \\
\text { disadvantaged } \\
\text { subsample } \\
(6)\end{array}$ \\
\hline & \multicolumn{6}{|c|}{ A. Grade 4, NABC, 2006} \\
\hline \multirow[t]{2}{*}{$A^{E}$} & $0.24^{* * *}$ & $0.14^{* * *}$ & $0.27^{* * *}$ & $0.26^{* * *}$ & $0.21^{* * *}$ & $0.25 * * *$ \\
\hline & $(0.00)$ & $(0.01)$ & $(0.01)$ & $(0.01)$ & $(0.01)$ & $(0.01)$ \\
\hline $\mathrm{N}$ & 83425 & 14973 & 16035 & 26775 & 4879 & 5132 \\
\hline F-statistic ${ }^{a}$ & 3134.87 & 156.11 & 777.02 & 2260.73 & 278.11 & 353.61 \\
\hline \multirow[t]{2}{*}{ Prob $F>0$} & 0.000 & 0.000 & 0.000 & 0.000 & 0.000 & 0.000 \\
\hline & \multicolumn{6}{|c|}{ B. Grade 8, NABC, 2006} \\
\hline \multirow{2}{*}{$A^{E}$} & $0.39 * * *$ & $0.34^{* * *}$ & $0.36^{* * *}$ & $0.37^{* * *}$ & $0.36^{* * *}$ & $0.32 * * *$ \\
\hline & $(0.00)$ & $(0.01)$ & $(0.01)$ & $(0.01)$ & $(0.01)$ & $(0.01)$ \\
\hline $\mathrm{N}$ & 81236 & 12332 & 17409 & 27313 & 4126 & 5936 \\
\hline F-statistic ${ }^{a}$ & 9444.35 & 970.54 & 1677.97 & 4231.03 & 620.31 & 639.04 \\
\hline \multirow[t]{2}{*}{ Prob $F>0$} & 0.000 & 0.000 & 0.000 & 0.00 & 0.000 & 0.000 \\
\hline & \multicolumn{6}{|c|}{ C. PIRLS, 2001} \\
\hline \multirow[t]{2}{*}{$A^{E}$} & $0.43^{* * *}$ & $0.25^{* * *}$ & $0.42^{* * *}$ & & & \\
\hline & $(0.02)$ & $(0.05)$ & $(0.04)$ & & & \\
\hline $\mathrm{N}$ & 4452 & 729 & 926 & & & \\
\hline F-statistic ${ }^{a}$ & 557.16 & 22.77 & 132.86 & & & \\
\hline \multirow[t]{2}{*}{ Prob $F>0$} & 0.000 & 0.000 & 0.000 & & & \\
\hline & \multicolumn{6}{|c|}{ D. TIMSS, 2003} \\
\hline \multirow[t]{2}{*}{$A^{E}$} & $0.46^{* * *}$ & $0.36^{* * *}$ & $0.43^{* * *}$ & & & \\
\hline & $(0.02)$ & $(0.06)$ & $(0.04)$ & & & \\
\hline $\mathrm{N}$ & 3158 & 430 & 784 & & & \\
\hline F-statistic ${ }^{a}$ & 485.04 & 34.36 & 105.28 & & & \\
\hline Prob $F>0$ & 0.000 & 0.000 & 0.000 & & & \\
\hline
\end{tabular}

Notes $A^{E}$ is expected school starting age. *Significant at the $10 \%$ level. ${ }^{*}$ Significant at the $5 \%$ level. ***Significant at the $1 \%$ level. Standard errors are in parentheses. ${ }^{a}$ The $F$-statistic corresponds to a test of the null hypothesis that the instrument is zero. 
Table A5 Chow test results, LATE estimates, Specification 1

\begin{tabular}{|c|c|c|c|c|}
\hline & $\begin{array}{c}\text { Dependent variable: } \\
\text { composite cognitive- } \\
\text { academic test score } \\
\text { (1) }\end{array}$ & $\begin{array}{l}\text { Dependent variable: } \\
\text { mathematics test } \\
\text { score } \\
(2)\end{array}$ & $\begin{array}{l}\text { Dependent variable: } \\
\text { reading test score } \\
\text { (3) }\end{array}$ & Discontinuity sample \\
\hline \multicolumn{5}{|c|}{ A. Grade 4, NABC, 2006} \\
\hline F-statistic ${ }^{a}$ & 4608.58 & 4975.71 & 1101.75615 & 1706.20 \\
\hline Prob $F>0$ & 0.000 & 0.000 & 0.000 & 0.000 \\
\hline$N$ & 31008 & 31008 & 31008 & 10011 \\
\hline \multicolumn{5}{|c|}{ B. Grade 8, NABC, 2006} \\
\hline F-statistic ${ }^{a}$ & 7803.45 & 6286.71 & 6621.24 & 2584.41 \\
\hline Prob $F>0$ & 0.000 & 0.000 & 0.000 & 0.000 \\
\hline $\mathrm{N}$ & 29741 & 29741 & 29741 & 10062 \\
\hline \multicolumn{5}{|c|}{ C. PIRLS, 2001} \\
\hline F-statistic ${ }^{a}$ & & & 288.59 & \\
\hline Prob $F>0$ & & & 0.000 & \\
\hline $\mathrm{N}$ & & & 1655 & \\
\hline \multicolumn{5}{|c|}{ D. TIMSS, 2003} \\
\hline F-statistic ${ }^{a}$ & & 282.47 & & \\
\hline Prob $F>0$ & & 0.000 & & \\
\hline $\mathrm{N}$ & & 1214 & & \\
\hline
\end{tabular}

